\title{
THE ROLE OF DIGITAL MEDIA IN IMAGE FORMATION: A STUDY ON THE PROJECTION OF CORPORATE IMAGE ON THE CONSUMER*
}

\author{
Sezgin SAVAŞ**, Sevimece KARADOĞAN DORUK***
}

Received: 18.12.2020 - Accepted: 24.03.2021

Savaş, S. and Karadoğan Doruk, S. (2021). The role of digital media in image formation: A study on the projection of corporate image on the consumer. Etkileşim, 7, 60-85. doi: 10.32739/etkilesim.2021.7.118

This study complies with research and publication ethics.

\begin{abstract}
In this article, how the corporate identity is reflected by the corporates through digital media, the level of formation of the corporate image in the desired direction as a result of identity presentation and the level of digital media dependence through image formation are analyzed. As part of the research, firstly, the digital media activities of corporations were analyzed through content analysis and the images that corporations tried to form on certain subjects were determined. Afterward, a questionnaire was applied to the consumers of these corporations to identify how the consumers perceived the corporations regarding the same subjects. As a result of the research, it has been revealed that the selected corporations were able to project the images they want to their consumers to a large extent. According to the results of the Chi-Square analysis carried out as part of the research, it was found that the perception of the corporate image by consumers is not dependent on digital media. In this regard, other activities (sponsorship, advertising, etc.) were proved to be more important than digital media activities during the image formation and maintenance stage.
\end{abstract}

Keywords: corporate culture, corporate identity, corporate image, digital media, corporate reflection.

* This article is derived from the PhD dissertation titled "The Role of Digital Media in Image Production: A Study on the Ratio of the Image Reflected to Consumers by Corporations" at istanbul University, in 2020.

** Assistant Professor/PhD, istanbul Gelişim University, Faculty of Economics, ssavas@gelisim.edu.tr, ORCID: 0000-0003-2141-1055

*** Professor (PhD), istanbul University, Faculty of Communication, ecek@istanbul.edu.tr, ORCID: 0000-0002-8911-6207 


\title{
IMAJÜRETIMINDE DIJITAL MEDYANIN ROLÜ: KURUMLARIN OLUŞTURMAYA ÇALIŞTIKLARI IMAJIN TÜKETICIYE NE ORANDA YANSIDIC̆INA YÖNELIK BIR ÇALIŞMA*
}

\author{
Sezgin SAVAŞ**, Sevimece KARADOĞAN DORUK***
}

Gönderim Tarihi: 18.12.2020 - Kabul Tarihi: 24.03.2021

Savaş, S. and Karadoğan Doruk, S. (2021). The role of digital media in image formation: A study on the projection of corporate image on the consumer. Etkileşim, 7, 60-85.

doi: 10.32739/etkilesim.2021.7.118

Bu çalışma araştırma ve yayın etiğine uygun olarak gerçekleştirilmiştir.

\section{Öz}

Bu makalede kurumsal kimliğin kurumlar tarafından dijital medya yoluyla nasıl yansıtıldığı, kimlik sunumu sonucu kurumsal imajın istenilen yönde oluşma düzeyi ve imaj oluşumu ile dijital medyanın bağımlılık düzeyi ortaya koyulmaktadır. Araştırma kapsamında, ilk olarak, içerik analizi ile kurumların dijital medya aktiviteleri incelenmiş ve belirli konularda kurumların oluşturmaya çalıştıkları imajlar tespit edilmiştir. Daha sonra ise kurumların tüketicilerine anket uygulanarak aynı konularda tüketicilerin kurumu nasıl algıladığı tespit edilmiştir. Araştırma sonucunda, seçilmiş olan kurumların istedikleri imajları tüketicilerine büyük ölçüde yansıtabildikleri ortaya çıkmıştır. Araştırma kapsamında gerçekleştirilmiş olan Ki-Kare analizi sonuçlarına göre, kurum imajının tüketiciler tarafından algılanmasının dijital medyaya bağımlı olmadığı bulunmuştur. Bu doğrultuda, imaj oluşturma ve sürdürme aşamasında dijital medya aktivitelerinden çok diğer aktivitelerin (sponsorluk, reklam vb.) önemli olduğu ortaya konulmuştur.

Anahtar Kelimeler: kurumsal kültür, kurumsal kimlik, kurumsal imaj, dijital medya, kurumsal dişavurum.

* Bu çalışma 2020 yılında istanbul Üniversitesi'nde tamamlanan "Imaj Üretiminde Dijital Medya'nın Rolü: Kurumların Oluşturmaya Çalıştıkları Imajın Tüketiciye Ne Oranda Yansıdığına Yönelik Bir Çalışma" adlı doktora tezinden üretilmiştir.

** Doktor Öğretim Üyesi, Gelişim Üniversitesi, iktisadi İdari ve Sosyal Bilimler Fakültesi, ssavas@gelisim.edu.tr, ORCID: 0000-0003-2141-1055

*** Profesör Doktor, İstanbul Üniversitesi, iletişim Fakültesi, ecek@istanbul.edu.tr, ORCID: 0000-0002-8911-6207

ISSN: 2636-7955 |Yıl 4 |Sayı 7 |Nisan 2021 | ETKíleşim| 


\section{Introduction}

In an environment dominated by the free market, where hundreds of actors produce the same product, the image of the corporations must be good for the product or service to be "attractive." Since even the products considered as the most important factor in the attractiveness of corporations have become standard, corporations have turned towards producing different activities to differentiate themselves. So, at this point, the image has become important.

A great variety of factors plays role in image formation today. It is possible to consider digital media activities, social responsibility projects, press releases, advertisements, and sponsorship, etc. among these factors. It is important to examine the activities in these areas separately and to determine the transfer ratio of the different or holistic images formed by each of these activities to the consumer. However, some corporations focus on certain channels and ignore others during the image formation stage and by leaving the media they consider worthless out of their general strategies and keeping them open to arbitrary discourse, these corporations think they can form images through short-term discourses reaching to limited space around certain strategies. Some corporations even think that the images they try to project after their limited activities are shaped in the minds of the consumers, just like in their own minds. However, this does not work as idealized, and certain problems are experienced during the image transition between the corporation and the consumer.

Corporations can learn about the images they hold in the eyes of consumers concretely by using various methods. In this process, having a "positive" image is considered more valuable than projecting the desired image. As frequently stated in the literature, it is important to have a positive image. However, in an era where corporations strategically manage all their activities, it is important to integrate strategically planned qualities suitable for the target audience instead of certain qualities that have been formed arbitrarily by others, even if positive. This is important because the image determines the nature of the thin line between the success and failure of a corporation as well as its lifetime.

\section{Literature Review: Theoretical Background}

The concept of corporate image, which can be defined as the view of a corporation in the eyes of stakeholders, has been frequently studied in the past with an administrative perspective and has been the subject of various research projects. For example, Virvilaite and Daubaraite (2011) revealed that corporate social responsibility, although not being the most important factor, positively contributes to corporate image. The research by Andreassen and Lindestad (1998) found out that the corporate image has an impact on 
perceived quality and customer satisfaction, but not on value, whereas it contributes indirectly to the perceived quality and value. The results showed that the corporate image has a significant but indirect effect on customer loyalty, claiming that customer loyalty is achieved both through the rejection of expectations and corporate image. Similarly, Weiwei (2007) aimed to define the relationship between corporate image and corporate reputation and their impact on customer loyalty.

The research by Cameran et al. (2010) examined the effect of corporate image and service quality on customer satisfaction in the professional service sector. This research revealed through Italian audit firms that the most important corporate image component for an audit firm is "usefulness". Claiming that the corporate image consists of social responsibility, product image, and corporate reputation, Ko et al. (2013) found that product image and corporate reputation have a direct impact on purchasing intent in the retail environment whereas social responsibility has an indirect effect.

One of the results of Chang and Fong's (2010) study of green product quality, green corporate image, green customer satisfaction and green customer loyalty is that the green corporate image has positive effects on green customer satisfaction and green customer loyalty. Ishaq (2012) found that the image has no effect in the stage of increasing customer loyalty and what matters is the service quality. Kim and Lee's (2010) research showed that the corporate image plays the most important role in creating and maintaining customer loyalty in the markets.

Flavian et al. (2005) found that corporate image affects trust in both traditional and internet banking. Moreover, the duration of the relationship was found to be effective in the intensity of the relationship between image and trust. Gatewood et al.'s (1993) research revealed that the image of a corporation is related to the present information (available, attainable, accessible).

Hu et al.'s (2009) research has shown that providing high-quality service and creating superior customer value can lead to high customer satisfaction, affecting the corporate image, and ultimately leading to consumer retention. The study emphasized that the positive image did not only help the corporation attract the customers but also positively affected the trust in the other related groups. Based on the idea that service quality, customer satisfaction, corporate image, and customer loyalty are important to deal with fierce competition and increase profit margins, Liat et al. (2014) revealed that all four variables are significantly interrelated and useful for promoting long-term business growth and ensuring sustainability. The research underlined that the quality of service affects customer satisfaction and the image of customer satisfaction, and the image affects customer loyalty.

The findings of Foroudi et al. (2014) research exploring the questions "What are the factors affecting the popularity of the corporate logo?" and 
"What are the main effects of this appreciation on corporate image and corporate reputation?" reveal that the popularity of a corporation's logo is projected to the extent that consumers see the logo positively. The work of Chung et al.'s (2015) results revealed that the effects in question, the corporate image was found to have a moderator effect on the relationship between corporate social responsibility and customer satisfaction as well.

The research conducted by Tsai and Yang (2010) found out that corporate product image, corporate citizenship image, and corporate reliability image are important elements for corporate attractiveness; and environmental sensitivity, which is one of the proposed applicant individual difference variables, moderating the relationship between corporate citizenship image and organizational attractiveness. The study of Huang et al. (2014) investigated the relationship between corporate social responsibility, service quality, corporate image, and purchasing intentions. The important result of this study is that corporate social responsibility has a significant positive impact on corporate image, service quality and purchasing intent.

As we can see, the concept of image is generally considered as an independent variable in the literature and evaluations have been made in the context of the effect of the image on something. Secondly, studies conducted have had the image as the dependent variable and measured the variables affecting the image. In this context, the aim has been to analyze what the image does, what it is effective on, and what affects the image rather than its quality. However, the questions of how the image is evaluated, whether the corporations can hold the images they portray or not, have drawn the interest of a limited number of studies (e.g. Savaş, 2016; Hatch and Schultz, 2011; Brown and Starkey, 2000; Brown, 1997).

Articles on image act on certain preliminary assumptions. Although it is important to assume that the positive image gives good results and the negative image gives bad results, the quality of image production and the gaps between the ends producing and receiving the image and transforming it by integrating the image with their own experiences, constitute the most important part of the image issue. The fact that there are only a limited number of articles on this issue in the literature is striking. Although there are theoretical articles on the subject, empirical studies seem to be inadequate. This study, on the other hand, aims to present the issue concretely by collecting information through surveys and different data collection tools and performing sectoral analysis. What matters is not the generalization of the image in positive or negative categories; it is the details of the image's quality based on the idea that the images created by each corporation's distinctive cultures and the subsequent projection of their identities are unique. Therefore, creating the image as desired by the corporation is important both in terms of being unique and the competitive advantage as an outcome of being unique.

There is a literature on concepts such as dysfunction that corporations 64 | ETKíleşim |Yıl 4 |Sayı 7| Nisan 2021 
experience while getting away from the truth in the formation of corporate culture, identity and the transfer of the image. Corporations might get carried away in a wave of imitating their rivals in an attempt to be "the latest trend" due to the possibility of losing their weight in the market or competition, or they might not be able to control their inner beliefs about who they are and become something that no one else believes in except for themselves (Hatch and Schultz, 2011: 76-77). Therefore, it is important for corporations to carefully construct their cultures and present their identity, which is an output of the culture, as a result of planned steps, and to design a planned strategy based on reality rather than discourse during image formation. An image based on narcissism or false perceptions also distorts the image perception curve between the corporation and the target audience: "Andrew Brown extended this idea to organizations by defining organizational narcissism as a dysfunction of the collective need for self-esteem, a complex consisting of denial, rationalization, self-aggrandizement, egotism, a sense of entitlement, and anxiety" (As cited in Hatch and Schultz, 2008: 63).

At first glance, it can be thought that this occurs due to the desire to be successful. Today, corporations hold the opinion that the way to be successful is to integrate with positive features in the eyes of the target audience. If the image is positive, this will positively affect consumer behavior such as purchasing (Marangoz, 2006: 111). Indeed, the corporations that do not have positive features as mentioned can think that they can be viewed positively through discourses. While implementing this strategy, there are those who think that the strategy will actually work as well as the ones who adopt the strategy in question as "real." However, ultimately, this is a disruption in the perception of "reality" and is extremely crucial for the lives of corporations.

The existence of such a problem brings out the need to reveal the image the corporations attempt to form through digital media and to look at how much is projected on the consumers by analyzing their discourse and actions in the context of the image they try to create. The role of digital media in terms of projecting the image correctly to consumers is also important today. However, it can be argued that the components that make up the image should be mentioned primarily.

\section{Corporate personality}

The first component of corporate identity can be defined as corporate core personality. Corporations are established by a specific person or group. Therefore, it is not possible to evaluate the corporation independently of the value judgments and opinions of the relevant "founders" law: "When a company is formed by the union of natural persons, a new real person," (Machen, 1911: 256) becomes a person representing the sum of its creators. Personality is considered as to what someone actually is (McCrae and Costa, 1982: 1283). In this context, it can be said that the corporate personality of the corporation 
comes before the corporate culture and corporate identity and represents the first existence of the corporation in its non-interacting form with the stakeholders.

\section{Corporate culture}

The second component of corporate identity can be defined as corporate culture: "Corporate culture refers to a core set of attitudes and practices that are shared by the members of the firm" (as cited in Tellis et al, 2009: 6). Just as a community has its own rules, the corporation as a community needs similar rules: "Corporate culture is a set of broad, tacitly understood rules which tell employees what to do under a wide variety of unimaginable circumstances" (Camerer and Vepsalainen, 1988: 115), so it is one of the essential requirements for employees to act in harmony and collaboration.

To manage the culture, it is necessary to understand what culture is, what it encompasses and how it should be evaluated (Schein, 2009: 20). Especially in the context of corporate culture, being able to create a new culture includes various elements. People come from different ethnic identities, cultural structures, and have different personality traits thanks to their past experiences (Sadri and Lees, 2001: 853). It can be thought that this situation brings along a basic adaptation problem. Therefore, creating a harmonious working environment requires certain common, guiding norms. At this point, corporate culture comes into play. Corporate culture determines the values, beliefs, and attitudes of the members (Kerr and Slocum, 1987: 99). As a result of this determination, individuals with different cultural backgrounds become integrated with the "new and shared" culture.

\section{Corporate identity}

Corporate identity describes one of the two main components of its corporate image. Corporate identity, as a representation of the corporation, is a means of presenting a tangible entity. In this context, it is the main element that the consumer can look at during the formation of the image. Besides, corporate culture is a prerequisite for differentiation, in other words, being unique.

It is said that the concept of corporate identity should now also be considered in the context of the real characteristics that give the corporation its originality, stability, and consistency, or in other words, the characteristics of the corporation. The rationale underlying this orientation is considered as not only an appearance reflected in visual design and communication but also as an interest in the importance of "what or who the corporation is", which mainly covers the corporation's specific strategies and culture (Cornelissen et al, 2007: 6-7).

66 | ETKíleşim |Yıl 4 |Sayı 7 Nisan 2021 


\section{Corporate image}

When we look at the concept of corporate image, we see that this concept is related to the judgments in the consumer's mind that result from the behavior and discourses of the corporation. For example, Marken (1990: 21) defines the corporate image as the perception of the goals and plans of the whole corporation. According to Richard and Zhang (2012: 572), the corporate image is the general impression left in the mind of the customer.

According to Vos (1992: 28), the corporate image is the general view of the corporation experienced by various stakeholders. It is based on people's minds, it is personal and also linked to time. Since the corporate image is variable, it may vary from person to person. Corporate identity is all messages conveyed by the corporation, and the corporate image is the perception that these messages reveal to stakeholders. These perceptions include interpretation, in other words, this interpretation state forms the image. Therefore, while corporate identity is a means of self-promotion, the image is the picture of the corporation drawn by stakeholders (Baskan Karsak, 2009: 115). Consumers perceive the corporate identity and form their own image of corporate identity as a result of their experiences and expectations with the corporation (Karadoğan Doruk and Savaş, 2017: 105).

\section{Study}

\section{Purpose of the study}

The purpose of this article is to discuss how corporations project their corporate identity through digital media, whether the images of corporations are formed in the minds of the consumers in the desired direction after the presentation of identity, and the level of dependence of the image formation process on digital media through examples of sectoral competitors.

\section{Originality of the study}

Similar to the design of this study, Page (2014) counted Twitter posts, focusing on whether corporations use Twitter as a tool to apologize. Özgen and Elmasoğlu (2016), on the other hand, examined the tweets of three airline companies in terms of the topics and message direction. Similar to a certain part of this study, the researchers in question counted tweets. Instead of focusing on only one digital media channel, this study focuses on the most popular digital media channels, corporate websites, press releases and news that corporations use as a tool to express themselves.

\section{Research hypothesis}

In this study, in order to compare the perception of the consumer with the perception of the corporations, the following hypotheses were created. 
Table 1. Research hypotheses

\begin{tabular}{|c|c|c|c|c|c|}
\hline $\mathrm{HO}$ & \multicolumn{5}{|c|}{$\begin{array}{c}\text { Visiting digital media pages of corporations/brands and perception of corpo- } \\
\text { rations/brands are independent. }\end{array}$} \\
\hline 豆 & $\begin{array}{l}\text { Visiting Eti's digital } \\
\text { media pages and } \\
\text { perception of Eti } \\
\text { are interdepen- } \\
\text { dent. }\end{array}$ & $\stackrel{\cong}{エ}$ & $\begin{array}{l}\text { Visiting Torku's digital } \\
\text { media pages and the } \\
\text { perception of Torku } \\
\text { are interdependent. }\end{array}$ & $\stackrel{m}{I}$ & $\begin{array}{l}\text { Visiting Ülker's digi- } \\
\text { tal media pages and } \\
\text { perception of Ülker } \\
\text { are interdependent. }\end{array}$ \\
\hline$\stackrel{\check{\Gamma}}{\dot{I}}$ & $\begin{array}{l}\text { Visiting Eti's digital } \\
\text { media pages and } \\
\text { perception of Eti's } \\
\text { mood are interde- } \\
\text { pendent. }\end{array}$ & $\stackrel{\check{I}}{\stackrel{1}{I}}$ & $\begin{array}{c}\text { Visiting Torku's digital } \\
\text { media pages and per- } \\
\text { ceiving what flavors/ } \\
\text { tastes Torku likes the } \\
\text { most are interdepen- } \\
\text { dent. }\end{array}$ & $\bar{m}$ & $\begin{array}{l}\text { Visiting Ülker's } \\
\text { digital media pages } \\
\text { and the perception } \\
\text { of Ülker's mood are } \\
\text { interdependent. }\end{array}$ \\
\hline 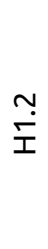 & $\begin{array}{l}\text { Visiting Eti's digital } \\
\text { media pages and } \\
\text { the perception of } \\
\text { the means of trans- } \\
\text { portation that Eti } \\
\text { brings forward are } \\
\text { interdependent. }\end{array}$ & $\stackrel{\sim}{\dddot{I}}$ & $\begin{array}{l}\text { Visiting Torku's digital } \\
\text { media pages and the } \\
\text { perception of which } \\
\text { city Torku is from are } \\
\text { interdependent. }\end{array}$ & $\begin{array}{l}\stackrel{\sim}{I} \\
\stackrel{m}{I}\end{array}$ & $\begin{array}{c}\text { Visiting Ülker's } \\
\text { digital media pages } \\
\text { and the perception } \\
\text { of the age group } \\
\text { that Ülker is in most } \\
\text { accord with are inter- } \\
\text { dependent. }\end{array}$ \\
\hline$\frac{m}{\text { 官 }}$ & $\begin{array}{l}\text { Visiting Eti's digital } \\
\text { media pages and } \\
\text { perception of what } \\
\text { Eti would pay at- } \\
\text { tention to in terms } \\
\text { of food are inter- } \\
\text { dependent. }\end{array}$ & $\stackrel{m}{\mathfrak{I}}$ & $\begin{array}{l}\text { Visiting Torku's digital } \\
\text { media pages and the } \\
\text { perception of Torku's } \\
\text { occupation are inter- } \\
\text { dependent. }\end{array}$ & $\begin{array}{l}m \\
\stackrel{m}{I}\end{array}$ & $\begin{array}{l}\text { Visiting Ülker's digi- } \\
\text { tal media pages and } \\
\text { the perception of } \\
\text { the snack that Ülker } \\
\text { would consume the } \\
\text { most are interdepen- } \\
\text { dent. }\end{array}$ \\
\hline$\stackrel{+}{\stackrel{+}{\Gamma}}$ & $\begin{array}{l}\text { Visiting Eti's digital } \\
\text { media pages and } \\
\text { perception of Eti's } \\
\text { lifestyle are inter- } \\
\text { dependent. }\end{array}$ & $\stackrel{+}{i}$ & $\begin{array}{l}\text { Visiting Torku's digi- } \\
\text { tal media pages and } \\
\text { perceiving the act } \\
\text { that makes Torku the } \\
\text { happiest are interde- } \\
\text { pendent. }\end{array}$ & $\stackrel{\stackrel{\oplus}{I}}{\dddot{m}}$ & $\begin{array}{l}\text { Visiting Ülker's digi- } \\
\text { tal media pages and } \\
\text { the perception of } \\
\text { which sports Ülker } \\
\text { would engage in } \\
\text { most are interdepen- } \\
\text { dent. }\end{array}$ \\
\hline 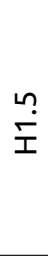 & $\begin{array}{l}\text { Visiting Eti's digital } \\
\text { media pages and } \\
\text { the perception of } \\
\text { the age group that } \\
\text { Eti is in most ac- } \\
\text { cord with are inter- } \\
\text { dependent. }\end{array}$ & $\stackrel{n}{\dddot{n}}$ & $\begin{array}{l}\text { Visiting Torku's digital } \\
\text { media pages and the } \\
\text { perception of what } \\
\text { Torku thinks is im- } \\
\text { portant to succeed in } \\
\text { business are interde- } \\
\text { pendent. }\end{array}$ & $\stackrel{\stackrel{n}{m}}{\dddot{m}}$ & $\begin{array}{c}\text { Visiting Ülker's digi- } \\
\text { tal media pages and } \\
\text { the perception of } \\
\text { Ülker's view of inno- } \\
\text { vations are interde- } \\
\text { pendent. }\end{array}$ \\
\hline$\stackrel{\varphi}{\stackrel{0}{x}}$ & $\begin{array}{l}\text { Visiting Eti's digital } \\
\text { media pages and } \\
\text { the perception of } \\
\text { Eti's attitude in } \\
\text { friendship relations } \\
\text { are interdepen- } \\
\text { dent. }\end{array}$ & 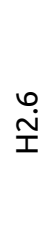 & $\begin{array}{l}\text { Visiting Torku'sdigital } \\
\text { media pages and the } \\
\text { perception of which } \\
\text { country Torku is a } \\
\text { citizen of are interde- } \\
\text { pendent. }\end{array}$ & $\stackrel{\stackrel{0}{\dot{m}}}{\stackrel{2}{I}}$ & $\begin{array}{c}\text { Visiting Ülker's digi- } \\
\text { tal media pages and } \\
\text { the perception of } \\
\text { the subject that } \\
\text { Ülker is most inter- } \\
\text { ested in are interde- } \\
\text { pendent. }\end{array}$ \\
\hline
\end{tabular}




\begin{tabular}{|c|c|c|c|c|c|}
\hline 竞 & $\begin{array}{l}\text { Visiting Eti's digital } \\
\text { media pages and } \\
\text { perception of Eti's } \\
\text { attitude towards } \\
\text { the surrounding } \\
\text { problems are inter- } \\
\text { dependent. }\end{array}$ & 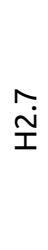 & $\begin{array}{l}\text { Visiting Torku's digital } \\
\text { media pages and the } \\
\text { perception of what } \\
\text { Torku would pay atten- } \\
\text { tion to most in a meal } \\
\text { are interdependent. }\end{array}$ & $\begin{array}{l}\hat{m} \\
\stackrel{M}{I}\end{array}$ & $\begin{array}{l}\text { Visiting Ülker's digi- } \\
\text { tal media pages and } \\
\text { the perception of } \\
\text { which country Ülker } \\
\text { is a citizen of are } \\
\text { interdependent. }\end{array}$ \\
\hline$\frac{\infty}{\stackrel{\infty}{I}}$ & $\begin{array}{l}\text { Visiting Eti's digital } \\
\text { media pages and } \\
\text { perceiving which } \\
\text { snack Etiwould } \\
\text { consume the most } \\
\text { are interdepen- } \\
\text { dent. }\end{array}$ & $\begin{array}{l}\stackrel{\infty}{\mathbb{I}} \\
\stackrel{1}{n}\end{array}$ & $\begin{array}{l}\text { Visiting Torku's digital } \\
\text { media pages and the } \\
\text { perception of which } \\
\text { drink Torku would en- } \\
\text { joy drinking the most } \\
\text { are interdependent. }\end{array}$ & $\begin{array}{l}\infty \\
\stackrel{m}{I}\end{array}$ & $\begin{array}{c}\text { Visiting Ülker's } \\
\text { digital media pages } \\
\text { and the perception } \\
\text { of Ülker's attitude } \\
\text { towards the game } \\
\text { when a game is be- } \\
\text { ing played are inter- } \\
\text { dependent. }\end{array}$ \\
\hline$\frac{\stackrel{9}{ \pm}}{\underline{I}}$ & $\begin{array}{l}\text { Visiting Eti's digital } \\
\text { media pages and } \\
\text { perception of Eti's } \\
\text { favorite color are } \\
\text { interdependent. }\end{array}$ & 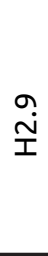 & $\begin{array}{l}\text { Visiting Torku's digital } \\
\text { media pages and the } \\
\text { perception of what } \\
\text { Torku would pay at- } \\
\text { tention to most when } \\
\text { buying a food product } \\
\text { are interdependent. }\end{array}$ & $\begin{array}{l}\stackrel{\leftrightarrow}{m} \\
\stackrel{M}{I}\end{array}$ & $\begin{array}{l}\text { Visiting Ülker's } \\
\text { digital media pages } \\
\text { and the perception } \\
\text { of Ülker's general } \\
\text { attitude towards the } \\
\text { work it does are in- } \\
\text { terdependent. }\end{array}$ \\
\hline $\begin{array}{l}\stackrel{\circ}{\check{I}} \\
\stackrel{\text { I }}{\text { In }}\end{array}$ & $\begin{array}{l}\text { Visiting Eti's digital } \\
\text { media pages and } \\
\text { the perception of } \\
\text { which country the } \\
\text { citizen of Eti is in- } \\
\text { terdependent. }\end{array}$ & $\begin{array}{l}\stackrel{0}{\mathfrak{I}} \\
\stackrel{1}{1}\end{array}$ & $\begin{array}{l}\text { Visiting Torku's digital } \\
\text { media pages and the } \\
\text { perception of wheth- } \\
\text { er Torku would pay } \\
\text { attention to domestic } \\
\text { production are inter- } \\
\text { dependent. }\end{array}$ & $\begin{array}{l}\stackrel{0}{\stackrel{m}{I}} \\
\stackrel{m}{1}\end{array}$ & $\begin{array}{l}\text { Visiting Ülker's digi- } \\
\text { tal media pages and } \\
\text { the perception of } \\
\text { what Ülker thinks } \\
\text { other people need } \\
\text { the most to gain are } \\
\text { interdependent. }\end{array}$ \\
\hline
\end{tabular}

\section{Limitations of the study}

The first limitation of the study is that it focuses only on corporations producing products such as biscuits, confectionery, chocolate, and wafers among food products within the non-durable consumer goods sector. The second limitation of the study is that, as mentioned earlier, it focuses only on digital media such as digital media activities, social responsibility projects, press releases, advertisements, and sponsorships among activities that can be reviewed to identify the image. The third limitation of the study is that it focuses only on the consumer in the context of the stakeholders.

\section{Sampling}

Corporations/brands producing products such as biscuits, confectionery, chocolate, wafers in Turkey constitute the universe of the study. The sampling is composed of the top three leading companies in the sector with the high- 
est net sales figures through the "Purposeful Sampling" method, which is not based on probability calculations. The three leading corporations in the relevant sector were identified using the numbers in the Fortune 500 Turkey list. According to the net sales category in the Fortune 500 list, Ülker is 37th, Eti is 59 th and Konya Şeker is 65 th. When the list in question is evaluated in terms of corporations producing foods such as biscuits, wafers, and chocolate, we see that Ülker ranks the first, Eti ranks the second and Konya Şeker ranks the third (Fortune Türkiye, 2018).

Table 2. Fortune 500 Turkey List

\begin{tabular}{|c|c|c|}
\hline Ranking & Corporation Name & Net Sales \\
\hline 37 & Ülker & $3.921,686,855$ \\
\hline 59 & Eti & $2.760,613,206$ \\
\hline 65 & Konya Şeker(Torku) & $2.516,549,435$ \\
\hline
\end{tabular}

The universe of the questionnaire to be carried out in the second phase of the study consists of people who buy products such as biscuits, confectionery, chocolate, wafers. In the process of sampling from the relevant universe, whether the three corporations mentioned are recognized or not is taken as reference. Sample selection was made in the form of "voluntary sampling": "In the voluntary sampling technique, the elements that make up the sample consist of people whom the researcher believes will find answers to their research problems or that they can reach most easily" (Kara and Kızılkaya, 2015: 11).

Given that Turkey's population is approximately 81 million (Kemp, 2018), the use of the relevant brands can reach up to millions. Since it is estimated that reaching 384 people in a universe above 1 million people will enable measurement with a sampling error of 0.05 (5\%) (Harper and Row, as cited in Sarantakos, 1993: 148), it can be said that the research is competent in terms of the number of samples.

\section{Method}

Qualitative and quantitative methods were used together in the study. While using content analysis for digital media activities within the scope of the qualitative research method; a questionnaire was used as a data collection tool as part of the quantitative research method. The reason why the mixed method is preferred is that the appropriate data collection tool changes at different stages of the research.

In the first step, the activities, actions, and discourses performed by the relevant corporation through digital media platforms were reviewed and a content analysis was made. In this context, these five categories were determined: press releases and news published by the corporations on corporate websites, all contents of corporate websites, Twitter and Facebook accounts. 
All the contents of the related categories were subjected to content analysis with the help of the Nvivo software and the ten most used concepts in the related content were determined. Then, concepts with the same word root and meaning are combined (e.g. farm, agriculture, etc.). All published content up to June 19,2018 , in press releases, news, and corporate website content, and all posts from the opening dates of pages until June 19, 2018, on Twitter and Facebook pages were received. The press releases category was not used for ülker as Ülker's website did not have such a section.

Later on, 10 concepts that stand out in each category were combined and the total usage amount was reached. Although the concept "share" seems to be the 7th concept used by Torku with 1734 use, it has been determined that the concept "share" amounted to such high numbers due to the "share" button on the website. In this context, the concept was excluded from the scope of analysis since it is not a concept that the corporation uses consciously, and therefore the 10th most used concept became "domestic/local." The resulting table was taken as a reference for the formation of the survey questions.

Table 3. Top 10 concepts used the most by the corporations/brands that are subject to the study

\begin{tabular}{|c|c|c|c|c|c|}
\hline \multicolumn{2}{|c|}{ ETi } & \multicolumn{2}{|c|}{ TORKU } & \multicolumn{2}{|c|}{ ÜLKER } \\
\hline Repetition & Concept & Repetition & Concept & Repetition & Concept \\
\hline 933 & Happy & 6274 & $\begin{array}{l}\text { Candy/ } \\
\text { Sugar }\end{array}$ & 2242 & Happy \\
\hline 758 & Bicycle & 5917 & Konya & 631 & Child \\
\hline 309 & Taste & 4180 & $\begin{array}{l}\text { Farmer, } \\
\text { farm, } \\
\text { agriculture, } \\
\text { field, etc. }\end{array}$ & 542 & Chocolate \\
\hline 262 & $\begin{array}{c}\text { Mobile, } \\
\text { active, etc. }\end{array}$ & 3851 & $\begin{array}{l}\text { Production, } \\
\text { producer, } \\
\text { etc. }\end{array}$ & 377 & Soccer \\
\hline 218 & Child & 2224 & We & 371 & New \\
\hline 202 & Social & 2115 & $\begin{array}{c}\text { Turkish, } \\
\text { Turkey, etc. }\end{array}$ & 340 & Art \\
\hline 177 & $\begin{array}{c}\text { Responsi- } \\
\text { bility }\end{array}$ & 1048 & Taste & 287 & $\begin{array}{l}\text { Turkish, Tur- } \\
\text { key, etc. }\end{array}$ \\
\hline 171 & Chocolate & 901 & Milk & 262 & To win \\
\hline 163 & Yellow & 862 & Natural & 225 & $\begin{array}{l}\text { Sustainabili- } \\
\text { ty, continui- } \\
\text { ty, etc. }\end{array}$ \\
\hline 160 & $\begin{array}{c}\text { Turkish, Tur- } \\
\text { key, etc. }\end{array}$ & 846 & $\begin{array}{l}\text { Domestic/ } \\
\text { Local }\end{array}$ & 169 & Chance \\
\hline
\end{tabular}

In the second stage, a personification questionnaire for the customers of the corporations was designed by using the key concepts determined in the 
first step. Survey questions were prepared based on symbolic analogy (simulation). Symbolic analogy focuses on what the products or brands represent by considering the products or brands as individuals or objects. This technique can provide free answers as it stimulates the imagination (Tığlı, 2003: 250). The study was not restricted to any criteria such as demographic, education, gender, and participants were reached face to face and via the internet.

The pilot implementation of the survey was carried out on thirty people between 07.15.2018 and 07.31.2018. Later, 433 people were surveyed between September 15 and November 15, and the profiles of the corporations in the consumer's mind were identified.

In the third stage, in the light of the data obtained in the first and second steps, comparisons were made on the profiles that were personified by the corporations and consumers. The comparison focused on the matching rate of the image the corporation tried to form with the image formed in the consumer's mind about the corporation in question.

In the fourth and last stage, whether image formation is dependent on digital media was determined. By examining the research hypotheses, both a contextual and a general picture were drawn, and the connection between digital media and image formation was examined.

Table 4. Cronbach's Alpha

\begin{tabular}{|c|c|}
\hline Cronbach's Alpha & Number of Questions \\
\hline .898 & 54 \\
\hline
\end{tabular}

Within the scope of the research, the Cronbach Alpha value was observed as 0.898 . Based on the condition that the Cronbach Alpha value is higher than 0.70 in terms of reliability (Gürbüz and Şahin, 2016: 325), it can be said that the survey conducted as part of the study has reliability.

\section{Findings}

\section{Demographic data}

A total of 433 people participated in the survey. Participants were asked a total of five questions constituting demographic elements. 
Table 5. Demographic data of research participants

\begin{tabular}{|c|c|c|c|c|c|}
\hline & Gender & Freq. & Perc. (\%) & & \\
\hline & Female & 285 & 65.8 & & \\
\hline & Male & 148 & 34.2 & & \\
\hline & Total & 433 & 100 & & \\
\hline Age & Freq. & Perc. (\%) & Education Status & Freq. & Perc. (\%) \\
\hline $17-20$ & 87 & 20.1 & Primary School & 15 & 3.5 \\
\hline $21-25$ & 111 & 25.6 & Middle School & 6 & 1.4 \\
\hline $26-30$ & 92 & 21.2 & High school & 75 & 17.3 \\
\hline $31-35$ & 48 & 11.1 & Associate Degree & 29 & 6.7 \\
\hline $36-40$ & 26 & 6 & Bachelor's Degree & 100 & 23.1 \\
\hline $41-45$ & 27 & 6.2 & Master's Degree & 82 & 18.9 \\
\hline $46-50$ & 18 & 4.2 & Doctorate & 37 & 8.5 \\
\hline $51+$ & 24 & 5.5 & Undergraduate Student & 89 & 20.6 \\
\hline Total & 433 & 100 & Total & 433 & 100 \\
\hline $\begin{array}{l}\text { Marital } \\
\text { Status }\end{array}$ & Freq. & Perc. (\%) & Revenue & Freq. & Perc. (\%) \\
\hline Married & 141 & 32.6 & $0-499$ & 94 & 21.7 \\
\hline Single & 280 & 64.7 & 500-999 TL & 45 & 10.4 \\
\hline Divorced & 7 & 1.6 & 1000-1499 TL & 33 & 7.6 \\
\hline $\begin{array}{l}\text { Has a } \\
\text { deceased } \\
\text { spouse }\end{array}$ & 5 & 1.2 & 1500-2499 TL & 74 & 17.1 \\
\hline \multirow[t]{3}{*}{ Total } & 433 & 100 & $2500-4000 \mathrm{TL}$ & 91 & 21 \\
\hline & & & $4000+$ & 96 & 22.2 \\
\hline & & & Total & 433 & 100 \\
\hline
\end{tabular}

When the demographic data of the research participants are analyzed, it is seen that women (65.8\%), singles (64.7\%) and people in the $21-25$ age group (25.6\%) mostly participated in the study. It is also observed that $23.1 \%$ of the participants have a bachelor's degree and $22.2 \%$ of them have an income of 4000 TL and above.

\section{Questions regarding the use of digital media}

The survey participants were asked a total of 6 questions aiming to reveal the general digital media usage practices and practices of visiting the digital media pages of the corporations addressed in the study. 
Table 6. Data on research participants' use of digital media

\begin{tabular}{|c|c|c|c|c|c|}
\hline D.M. Use & Freq. & $\begin{array}{c}\text { Perc. } \\
\text { (\%) }\end{array}$ & $\begin{array}{c}\text { Paying } \\
\text { attention } \\
\text { to D.M. } \\
\text { concepts }\end{array}$ & Freq. & Perc. (\%) \\
\hline Yes & 390 & 90.1 & Yes & 88 & 20.3 \\
\hline No & 43 & 9.9 & No & 27 & 6.2 \\
\hline Total & 433 & 100 & $\begin{array}{c}\text { NUDM\& } \\
\text { NVRDMP } 1\end{array}$ & 318 & 73.4 \\
\hline & & & Total & 433 & 100 \\
\hline
\end{tabular}

\begin{tabular}{|c|c|c|c|c|c|c|c|c|}
\hline $\begin{array}{l}\text { Eti's DM } \\
\text { Visit }\end{array}$ & Freq. & $\begin{array}{l}\text { Perc. } \\
\text { (\%) }\end{array}$ & $\begin{array}{c}\text { Torku's } \\
\text { DM Visit }\end{array}$ & Freq. & $\begin{array}{l}\text { Pct } \\
\text { (\%) }\end{array}$ & $\begin{array}{c}\text { Ülker's DM } \\
\text { Visit }\end{array}$ & Freq. & $\begin{array}{l}\text { Perc. } \\
(\%)\end{array}$ \\
\hline Yes & 65 & 15 & Yes & 59 & 13.6 & Yes & 56 & 12.9 \\
\hline No & 325 & 75.1 & No & 327 & 75.5 & No & 330 & 76.2 \\
\hline $\begin{array}{l}\text { Not using } \\
\text { D.M. }\end{array}$ & 43 & 9.9 & $\begin{array}{l}\text { Not using } \\
\text { D.M }\end{array}$ & 47 & 10.9 & $\begin{array}{l}\text { Not using } \\
\text { D.M. }\end{array}$ & 47 & 10.9 \\
\hline Total & 433 & 100 & Total & 433 & 100 & Total & 433 & 100 \\
\hline $\begin{array}{c}\text { Eti's } \\
\text { Frequen- } \\
\text { cy of DM } \\
\text { Visit }\end{array}$ & Freq. & $\begin{array}{l}\text { Perc. } \\
\text { (\%) }\end{array}$ & $\begin{array}{c}\text { Torku's } \\
\text { Frequen- } \\
\text { cy of DM } \\
\text { Visit } \\
\end{array}$ & Freq. & $\begin{array}{l}\text { Perc. } \\
(\%)\end{array}$ & $\begin{array}{l}\text { Ülker's } \\
\text { Frequen- } \\
\text { cy of DM } \\
\text { Visit }\end{array}$ & Freq & $\begin{array}{l}\text { Perc. } \\
\text { (\%) }\end{array}$ \\
\hline $\begin{array}{l}\text { More than } \\
\text { once a day }\end{array}$ & 2 & 0.5 & $\begin{array}{c}\text { More } \\
\text { than once } \\
\text { a day } \\
\end{array}$ & 3 & 0.7 & $\begin{array}{l}\text { More than } \\
\text { once a day }\end{array}$ & 1 & 0.2 \\
\hline $\begin{array}{c}\text { Once a } \\
\text { week on } \\
\text { average }\end{array}$ & 4 & 0.9 & $\begin{array}{c}\text { Once a } \\
\text { week on } \\
\text { average }\end{array}$ & 5 & 1.2 & $\begin{array}{c}\text { Once a } \\
\text { week on } \\
\text { average }\end{array}$ & 2 & 0.5 \\
\hline $\begin{array}{l}\text { Once a } \\
\text { month on } \\
\text { average }\end{array}$ & 8 & 1.8 & $\begin{array}{c}\text { Once a } \\
\text { month on } \\
\text { average }\end{array}$ & 8 & 1.8 & $\begin{array}{c}\text { Once a } \\
\text { month on } \\
\text { average }\end{array}$ & 10 & 2.3 \\
\hline Only once & 51 & 11.8 & Only once & 43 & 9.9 & Only once & 43 & 9.9 \\
\hline $\begin{array}{c}\text { NUDM\& } \\
\text { NVRDMP }\end{array}$ & 368 & 85 & $\begin{array}{c}\text { NUDM\& } \\
\text { NVRDMP }\end{array}$ & 374 & 86.4 & $\begin{array}{c}\text { NUDM\& } \\
\text { NVRDMP }\end{array}$ & 377 & 87.1 \\
\hline Total & 433 & 100 & Total & 433 & 100 & Total & 433 & 100 \\
\hline
\end{tabular}

As seen in Table 5, 90.1\% of the participants use digital media. However, the identified rates of digital media page visits to the three corporations were as follows: Eti $15 \%$, Torku $13.6 \%$, and Ülker $12.9 \%$. Looking at the visit frequency of digital media pages, we see a rate of $11.8 \%$ for Eti, $9.9 \%$ for Torku and $9.9 \%$ for Ülker within the scope of the "only once" option.

If we look at the ratio of participants paying attention to the concepts

Those who do not use digital media and do not visit the relevant digital media page. 
when they visit the relevant digital media pages, we see that $76.52 \%$ of the people who visited digital media pages (115 individuals) ${ }^{2}$ take note of the concepts that are used in the posts.

\section{Evaluation of frequency tables}

This section evaluates how often the concepts that refer to the survey questions are given as answers by the survey participants, in other words, what percentage of the most used concepts in the digital media is the answer that comes first to the consumer's mind in the relevant context.

Table 7. Eti - comparison of concepts and general survey answers

\begin{tabular}{|c|c|c|c|c|}
\hline Concept & $\begin{array}{l}\text { The } \\
\text { Corporation's } \\
\text { Self-Definition }\end{array}$ & $\begin{array}{l}\text { The Definition } \\
\text { Made by the } \\
\text { Consumers about } \\
\text { the Corporation }\end{array}$ & $\begin{array}{l}\text { Consumer } \\
\text { Response } \\
\text { Rate }\end{array}$ & \\
\hline Happy & Happy & Happy & $54.30 \%$ & \\
\hline Bicycle & Bicycle & Bicycle & $52.00 \%$ & \\
\hline Taste & Taste & Taste & $50.10 \%$ & \\
\hline $\begin{array}{l}\text { Mobile, active, } \\
\text { etc. }\end{array}$ & Mobile-Active & Mobile-Active & $85.90 \%$ & \\
\hline Child & Child & Young & $43.20 \%$ & $\begin{array}{c}\text { Child } \\
37.4 \%\left(2^{\text {nd }}\right. \\
\text { answer })\end{array}$ \\
\hline Social & Social, extrovert & Social, extrovert & $82.90 \%$ & \\
\hline Responsibility & $\begin{array}{l}\text { Realizes the } \\
\text { problems and } \\
\text { takes respon- } \\
\text { sibility for the } \\
\text { solution }\end{array}$ & $\begin{array}{l}\text { Realizes the prob- } \\
\text { lems and takes } \\
\text { responsibility for } \\
\text { the solution }\end{array}$ & $72.50 \%$ & \\
\hline Chocolate & Chocolate & Biscuit & $55.40 \%$ & $\begin{array}{c}\text { Chocolate } \\
25.6 \%\left(2^{\text {nd }}\right. \\
\text { answer) }\end{array}$ \\
\hline Yellow & Yellow & Red & $34.20 \%$ & $\begin{array}{c}\text { Yellow } \\
22.6 \%\left(2^{\text {nd }}\right. \\
\text { answer })\end{array}$ \\
\hline $\begin{array}{c}\text { Turkish, } \\
\text { Turkey, etc. }\end{array}$ & Turkey & Turkey & $58.40 \%$ & \\
\hline
\end{tabular}

The number of participants who have visited at least one digital media page of the relevant corporations is 115 . Since participants can specify that they have visited more than one corporation's page, the manual summation of the figures in Table 8 may give erroneous results. 
When Eti's questions are analyzed, it is seen that the answers of the participants match up with the most used concepts by Eti in digital media by a ratio of 7 out of 10 (70\%). Therefore, it can be seen that the concepts used by Eti on digital media significantly overlap with the consumer's perception of Eti. As an exception, it is seen that consumers give different answers in the 5th, 8th and 9th questions. Especially in the color question, it is seen that consumers marked the "red" option even though Eti emphasized the "yellow" color in digital media. It can be thought that the fact that Eti's logo is red might have an important effect on the foundation of this marking.

Table 8. Torku-comparison of concepts and general survey answers

\begin{tabular}{|c|c|c|c|}
\hline Concept & $\begin{array}{l}\text { The Corporation's } \\
\text { Self-Definition }\end{array}$ & $\begin{array}{l}\text { The Definition } \\
\text { Made by the } \\
\text { Consumers about } \\
\text { the Corporation }\end{array}$ & $\begin{array}{c}\text { Consumer } \\
\text { Response Rate }\end{array}$ \\
\hline Candy/Sugar & Sweet & Sweet & $61.90 \%$ \\
\hline Konya & Konya & Konya & $56.40 \%$ \\
\hline $\begin{array}{l}\text { Farmer, farm, agri- } \\
\text { culture, field, etc. }\end{array}$ & Farmer & Farmer & $64.40 \%$ \\
\hline $\begin{array}{l}\text { Production, pro- } \\
\text { ducer, etc. }\end{array}$ & To produce & To produce & $69.10 \%$ \\
\hline We & $\begin{array}{l}\text { Acting as a team } \\
\text { and bringing the } \\
\text { "we/us" feeling to } \\
\text { the fore }\end{array}$ & $\begin{array}{l}\text { Acting as a team } \\
\text { and bringing the } \\
\text { "we/us" feeling to } \\
\text { the fore }\end{array}$ & $84.30 \%$ \\
\hline $\begin{array}{c}\text { Turkish, Turkey, } \\
\text { etc. }\end{array}$ & Turkey & Turkey & $75.50 \%$ \\
\hline Taste & Taste & Taste & $47.30 \%$ \\
\hline Milk & Milk & Milk & $37.20 \%$ \\
\hline Natural & $\begin{array}{c}\text { The naturalness of } \\
\text { the product con- } \\
\text { tent }\end{array}$ & $\begin{array}{c}\text { The naturalness of } \\
\text { the product con- } \\
\text { tent }\end{array}$ & $64.90 \%$ \\
\hline Domestic/Local & Yes & Yes & $88.50 \%$ \\
\hline
\end{tabular}

When Torku's questions are analyzed, it is seen that the answers of the survey participants match up with the most used concepts by Torku in digital media by a ratio of 10 out of $10(100 \%)$. Therefore, it can be seen that the concepts used by Torku through digital media highly overlap with the consumer's perception of Torku. 
Table 9. Ülker - comparison of concepts and general survey answers

\begin{tabular}{|c|c|c|c|c|}
\hline Concept & $\begin{array}{c}\text { The } \\
\text { Corporation's } \\
\text { Self-Definition }\end{array}$ & $\begin{array}{l}\text { The Definition } \\
\text { Made by the } \\
\text { Consumers about } \\
\text { the Corporation }\end{array}$ & $\begin{array}{l}\text { Consumer } \\
\text { Response } \\
\text { Rate }\end{array}$ & \\
\hline Happy & Happy & Happy & $33.00 \%$ & \\
\hline Child & Child & Young & $32.80 \%$ & $\begin{array}{c}\text { Child } \\
\text { 26.8\% (2nd } \\
\text { answer) }\end{array}$ \\
\hline Chocolate & Chocolate & Chocolate & $38.60 \%$ & \\
\hline Soccer & Soccer & Basketball & $49.90 \%$ & $\begin{array}{c}\text { Soccer } \\
24.7 \%\left(2^{\text {nd }}\right. \\
\text { answer })\end{array}$ \\
\hline New & $\begin{array}{l}\text { It would pioneer } \\
\text { innovations }\end{array}$ & $\begin{array}{l}\text { It would pioneer } \\
\text { innovations }\end{array}$ & $40.00 \%$ & \\
\hline Art & Art & Sports & $49.40 \%$ & $\begin{array}{c}\text { Art } 14.3 \% \\
\left(2^{\text {nd }} \text { an- }\right. \\
\text { swer })\end{array}$ \\
\hline $\begin{array}{l}\text { Turkish, Turkey, } \\
\text { etc. }\end{array}$ & Turkey & Turkey & $61.70 \%$ & \\
\hline To win & $\begin{array}{c}\text { It would focus } \\
\text { on winning the } \\
\text { game }\end{array}$ & $\begin{array}{l}\text { It would focus on } \\
\text { winning the game }\end{array}$ & $55.00 \%$ & \\
\hline $\begin{array}{l}\text { Sustainability, } \\
\text { continuity, etc. }\end{array}$ & $\begin{array}{c}\text { It would contin- } \\
\text { ue the work it } \\
\text { started, it would } \\
\text { finish it }\end{array}$ & $\begin{array}{l}\text { It would contin- } \\
\text { ue the work it } \\
\text { started, it would } \\
\text { finish it }\end{array}$ & $79.40 \%$ & \\
\hline Chance & The Chance to & Diligence & $35.10 \%$ & $\begin{array}{l}7.9 \% \text { the } \\
\text { chance } \\
\text { to (5 } 5^{\text {th }} \text { an- } \\
\text { swer) }\end{array}$ \\
\hline
\end{tabular}

Analyzing Ülker's questions, we can see that the answers of the participants match up with the most used concepts by Ülker in digital media by a ratio of 6 in 10 (60\%). And it is observed that consumers gave different answers in questions 2, 4, 6 and 10. While Ülker emphasized "soccer" through digital media, consumers identified Ülkerwith "basketball" as a sport. Likewise, while Ülker emphasized "art", consumers emphasized "sports", and consumers emphasized "diligence" whereas Ülkeremphasized "luck." It seems safe to make a judgment and say that independent of digital media, especially in sports-related questions, sports sponsorships of Ülker are effective based on these markings. As to the concept of chance, it can be said that Ülker organizes competitions intensely on its digital media pages, using expressions such as "seize a chance to win", etc. intensively and therefore involuntarily emphasizes "luck" for success and creates a match between winning and luck, while consumers make an assessment based on Ülker's overall life success. 


\section{The effect of concepts used in digital media on consumer perception}

As seen in the previous section, a significant overlap is observed in the perceptions of corporations in the eyes of general consumers in the given issues and contexts, and the concepts used by the corporations through digital media. There is a possibility that this outcome will be compromised from other activities of the institution such as sponsorships and advertisements. Accordingly, in this section, the Chi-Square analysis was conducted to compare the answers of consumers who visited the digital media pages of the corporations that were the subject of the research and those who did not. The reason for choosing the Chi-square independence test within the research is that the questionnaire form has a nominal scale (Erdoğan, 2012: 298).

Table 10. Chi-Square Analysis Results

\begin{tabular}{|c|c|c|c|c|c|}
\hline \multicolumn{2}{|c|}{$\begin{array}{c}\text { Visiting Eti's Digital Me- } \\
\text { dia Pages }\end{array}$} & \multicolumn{2}{|c|}{$\begin{array}{c}\text { Visiting Torku's Digital } \\
\text { Media Pages }\end{array}$} & \multicolumn{2}{|c|}{$\begin{array}{c}\text { Visiting Ülker's Digital } \\
\text { Media Pages }\end{array}$} \\
\hline Question & $\begin{array}{l}P \text { and } V \\
\text { value }\end{array}$ & Question & $\begin{array}{l}P \text { and } V \\
\text { value }\end{array}$ & Question & $\begin{array}{l}P \text { and } V \\
\text { value }\end{array}$ \\
\hline Eti's Mood & $p=0.598$ & $\begin{array}{l}\text { What } \\
\text { Tastes/Fla- } \\
\text { vors Torku } \\
\text { Likes Most }\end{array}$ & $p=0.730$ & $\begin{array}{l}\text { Ülker's } \\
\text { Mood }\end{array}$ & $p=0.480$ \\
\hline $\begin{array}{l}\text { Eti's Trans- } \\
\text { portation } \\
\text { Vehicle }\end{array}$ & $p=0.473$ & $\begin{array}{l}\text { Which City } \\
\text { Torku is } \\
\text { from }\end{array}$ & $p=0.310$ & $\begin{array}{l}\text { The Age } \\
\text { Group that } \\
\text { Ülker Gets } \\
\text { along with } \\
\text { the Best }\end{array}$ & $p=0.179$ \\
\hline $\begin{array}{l}\text { What Eti } \\
\text { would Pay } \\
\text { Attention } \\
\text { to in terms } \\
\text { of Food }\end{array}$ & $p=0.468$ & $\begin{array}{l}\text { Torku's Oc- } \\
\text { cupation }\end{array}$ & $p=0.238$ & $\begin{array}{l}\text { The Snack } \\
\text { that Ülker } \\
\text { would Con- } \\
\text { sume Most }\end{array}$ & $p=0.890$ \\
\hline $\begin{array}{l}\text { Eti's Life- } \\
\text { style }\end{array}$ & $p=0.108$ & $\begin{array}{l}\text { The Action } \\
\text { That Makes } \\
\text { Torku Hap- } \\
\text { piest }\end{array}$ & $p=0.668$ & $\begin{array}{l}\text { The Sports } \\
\text { Ülker Will } \\
\text { be Most } \\
\text { Engaged In }\end{array}$ & $p=0.383$ \\
\hline $\begin{array}{l}\text { The Age } \\
\text { Group that } \\
\text { EtiGets } \\
\text { along with } \\
\text { the Best }\end{array}$ & $p=0.707$ & $\begin{array}{l}\text { What Torku } \\
\text { would Think } \\
\text { is Important } \\
\text { to Succeed } \\
\text { in a Job }\end{array}$ & $p=0.101$ & $\begin{array}{l}\text { Ülker's } \\
\text { Perspective } \\
\text { on } \\
\text { Innovations }\end{array}$ & $p=0.915$ \\
\hline $\begin{array}{l}\text { Eti's At- } \\
\text { titude } \\
\text { towards } \\
\text { Friendships }\end{array}$ & $p=0.309$ & $\begin{array}{l}\text { Which } \\
\text { Country } \\
\text { Torku is a } \\
\text { Citizen of }\end{array}$ & $p=0.188$ & $\begin{array}{l}\text { The Topic } \\
\text { that Ülker is } \\
\text { Most Inter- } \\
\text { ested in }\end{array}$ & $p=0.997$ \\
\hline
\end{tabular}




\begin{tabular}{|c|c|c|c|c|c|}
\hline $\begin{array}{l}\text { Eti's At- } \\
\text { titude } \\
\text { toward } \\
\text { Problems } \\
\text { Around It }\end{array}$ & $p=0.152$ & $\begin{array}{l}\text { What Torku } \\
\text { would Pay } \\
\text { Attention } \\
\text { Most in a } \\
\text { Meal }\end{array}$ & $p=0.754$ & $\begin{array}{l}\text { Which } \\
\text { Country } \\
\text { Ülker is a } \\
\text { Citizen of }\end{array}$ & $p=0.090$ \\
\hline $\begin{array}{l}\text { Which } \\
\text { Snack Eti } \\
\text { Would Con- } \\
\text { sume Most }\end{array}$ & $p=0.365$ & $\begin{array}{l}\text { What Drink } \\
\text { Would } \\
\text { Torku Enjoy } \\
\text { Most }\end{array}$ & $p=0.460$ & $\begin{array}{l}\text { Ülker's } \\
\text { Attitude } \\
\text { towards the } \\
\text { Game when } \\
\text { Playing a } \\
\text { Game }\end{array}$ & $p=0.835$ \\
\hline $\begin{array}{l}\text { Eti's Favor- } \\
\text { ite Color }\end{array}$ & $p=0.315$ & $\begin{array}{l}\text { What Torku } \\
\text { would Pay } \\
\text { Attention } \\
\text { to Most } \\
\text { when Buy- } \\
\text { ing a Food } \\
\text { Product }\end{array}$ & $\begin{array}{l}\mathrm{p}=0.006 \\
V=0.183\end{array}$ & $\begin{array}{l}\text { Ülker's } \\
\text { General } \\
\text { Attitude } \\
\text { towards Its } \\
\text { Job }\end{array}$ & $p=0.670$ \\
\hline $\begin{array}{l}\text { Which } \\
\text { Country Eti } \\
\text { is a Citizen } \\
\text { of }\end{array}$ & $p=0.472$ & $\begin{array}{l}\text { Whether } \\
\text { Torku would } \\
\text { Pay At- } \\
\text { tention to } \\
\text { Domestic } \\
\text { Production }\end{array}$ & $\begin{array}{l}\mathrm{p}=0.035 \\
V=0.101\end{array}$ & $\begin{array}{l}\text { What Ülker } \\
\text { Thinks Oth- } \\
\text { er People } \\
\text { Need Most } \\
\text { to Gain } \\
\text { Something }\end{array}$ & $p=0.376$ \\
\hline
\end{tabular}

Firstly, as seen in the table, visiting Eti's digital media pages and perception of Eti's mood are independent ( $P$-value $=0.598$; $P$ value $>0.05$ ). In this context, it was found that the H1.1 hypothesis of the research was not supported. Similarly, independence was also detected for all other sub-hypotheses. Within the scope of the research, H1.2 hypothesis ( $P$ value $=0.473 ; P$ value $>0.05$ ), H1.3 hypothesis $(P=0.468 ; P>0.05), H 1.4$ hypothesis $(P=0.108 ; P>0.05), H 1.5$ hypothesis $(P=0.707 ; P>0.05), H 1.6$ hypothesis $(P=0.309 ; P>0.05), H 1.7$ hypothesis $(P=0.152 ; P>0.05), H 1.8$ hypothesis $(P=0.365 ; P>0.05), H 1.9$ hypothesis $(P=0.315 ; P>0.05)$, and $H 1.10$ hypothesis $(P=0.472 ; P>0.05)$ were not supported.

Secondly, as seen in the table, visiting Torku's digital media pages is independent of the perception of what flavors Torku likes the most $(P$ value= 0.730; $P$ value>0.05). In this context, it was observed that the H2.1 hypothesis of the research was not supported. Similarly, independence was determined for all other sub-hypotheses with two exceptions. Within the scope of the research, H2.2 hypothesis ( $P=0.310 ; P>0.05), H 2.3$ hypothesis $(P=0.238 ; P>0.05)$, H2.4 hypothesis $(P=0.668 ; P>0.05) H 2.5$ hypothesis $(P=0.101 ; P>0.05), H 2.6$ hypothesis $(P=0.188 ; P>0.05), H 2.7$ hypothesis $(P=0.754 ; P>0.05), H 2.8$ hypothesis $(P=0.460 ; P>0.05)$ were not supported. However, the H2.9 hypothesis $(P=0.006 ; P<0.05)$ and the $H 2.10$ hypothesis $(P=0.035 ; P<0.05)$ were supported. The dependency level was found to be weak for both hypotheses $(V=0.183$; $\mathrm{V}<0.30-\mathrm{V}=0.101 ; \mathrm{V}<0.30$ ). 
Thirdly, as seen in the table, visiting Ülker's digital media pages and the perception of Ülker's mood are independent $(P=0.480 ; P>0.05)$. In this context, it was observed that the H3.1 hypothesis of the research was not supported. Within the scope of the research, H3.2 hypothesis $(P=0.179 ; P>0.05)$, H3.3 hypothesis $(P=0.890 ; P>0.05), H 3.4$ hypothesis $(P=0.383 ; P>0.05), H 3.5$ hypothesis $(P=0.915 ; P>0.05), H 3.6$ hypothesis $(P=0.997 ; P>0.05), H 3.7$ hypothesis $(P=0.090 ; P>0.05), H 3.8$ hypothesis $(P=0.835 ; P>0.05), H 3.9$ hypothesis $(P=0.670 ; P>0.05)$ and $H 3.10$ hypothesis $(P=0.376 ; P>0.05)$ were not supported.

Within the scope of the research, 3 of the hypotheses were supported while 31 were not. The test results of $\mathrm{HO}, \mathrm{H} 1, \mathrm{H} 2$ and $\mathrm{H} 3$ hypothesis, which are the main hypotheses of the study attempting to reveal the role of digital media channels in the stage of corporations/brands self-definition and consumers' perception of corporations/brands, revealed that the perception of the corporation/brand is not dependent on digital media. In this context, a valuable result has emerged that the concepts are not strong enough.

It can be said that the perception consistency between the corporation/ brand and the consumer is formed by the general activities of the corporations, and the corporations are consciously using these themes in their digital media activities. While the question of which activity on which media was the most important factor in the perception of the corporation remains ambiguous, the data of this study only revealed the importance of digital media and the concepts used in digital media.

\section{Discussion}

Image formation or, determining which elements are effective in the image formation process is challenging. While corporations present an identity to form an image in line with their own wishes, whether consumers perceive the identity presentation in question or how much of it they perceive represents an important point.

With the results of this study, it was seen that all three corporations/ brands were able to achieve significant consistency at the stage of defining themselves and being defined by the consumers, and they were successful in ensuring that consumers understand their corporations/brands. Within the study, the relevant corporations/brands have provided consistency between introducing themselves and defined by the consumers at a rate of $70 \%, 100 \%$, and $60 \%$ respectively. This data proves the success of the relevant corporations/brands in image formation and maintenance.

Another result of the research findings is that it provides inferences about the function of digital media, which is thought to be an important medium in image formation. The research results revealed that digital media can only be used as a supportive medium, and digital media does not have enough pow-

80 | ETKíleşim | Yıl 4 |Sayı 7 | Nisan 2021 
er to form and maintain images. Within the study, there was an attempt to identify whether the answers given to the questions are dependent on digital media or not, and the test results of the hypotheses have revealed the inadequacy of the power of digital media except for two sub-hypotheses. This result prepares an infrastructure for the inference that traditional methods still have a more important place in the image formation process than digital media.

While $90.1 \%$ of the participants in the study uses digital media, only $26.5 \%$ of these participants visit the digital media channels of the relevant brands/ corporations. In this context, one can argue that the main medium used by digital media users to search for information about products such as biscuits within the non-durable consumer goods sector is not digital media. Although a considerable part of the participants, approximately one fourth, visited the digital media channels of the relevant corporations/brands, the visit frequency of the participants was significantly low. In the survey, 51 (78\%) of Eti's visitors, 43 (72\%) of Torku's visitors, and 43 (76\%) of Ülker's visitors stated that they visited the relevant digital media "only once." Therefore, a "continuous" visit situation seems to be very limited and is possible only at a monthly level rather than daily or weekly use. Corporations need to follow this issue closely. Accordingly, it can be said that, as a priority, studies should be carried out to increase the interest in digital media channels in addition to somehow updating the pages continuously.

The fact that 88 of the 115 (26.5\%) people who visited the digital media channels stated that they pay attention to the concepts reveals how important the concepts actually are. Since consumers note paying attention to the concepts used, it can be said that corporations/brands should pay attention when choosing concepts. Although it has been determined in this research that the concepts do not have a dramatic effect, it should also be remembered that a sentence or word used at the wrong time may cause great problems for corporations/brands.

It should not be forgotten that image formation refers to a two-way process. Besides the importance of how consumers define a corporation, it is also important how the corporation wants to project itself and how it desires to be perceived by consumers. It is no longer sufficient to be perceived positively by the consumer; a new period has emerged and now corporations need to differentiate themselves. In this period, rather than having random good qualities, it is important to have strategically planned qualities in essence, not just in words, and also to get these qualities perceived as desired by the consumer. Meeting of the consumer perceptions with the corporate identity, which is based on reality and planned by the corporation, and turning into an image as desired, directly affects the success of the corporation. Therefore, new approaches are needed in the repetitive image literature. At this point, separating the elements in the image formation process and the effects of these 
elements to the finest details, and using different methods to go beyond the usual limits can be considered as an important starting point.

\section{References}

Andreassen, T. W. and Lindestad, B. (1998). The effect of corporate image in the formation of customer loyalty. Journal of Service Research, 1(1), 82-92.

Başkan Karsak, B. (2009). Logo değişiminin kurumsal kimlik ve kurumsal imajla bağlantısı: Unilever örneği. Marmara iletişsim Dergisi, 15, 113-120.

Brown, A. D. (1997). Narcissism, identity, and legitimacy. Academy of Management Review, 22(3), 643-686.

Brown, A. D. and Starkey, K. (2000). Organizational identity and learning: A psychodynamic perspective. Academy of management review, 25(1), 102-120.

Cameran, M., Moizer, P. and Pettinicchio, A. (2010). Customer satisfaction, corporate image, and service quality in professional services. The Service Industries Journal, 30(3), 421-435.

Camerer, C. and Vepsalainen, A. (1988). The economic efficiency of corporate culture. Strategic Management Journal, 9, 115-126.

Chang, N. J. and Fong, C. M. (2010). Green product quality, green corporate image, green customer satisfaction, and green customer loyalty. African Journal of Business Management, 4(13), 2836-2844.

Chung, K. H., Yu, J. E., Choi, M. G. and Shin, J. I. (2015). The effects of CSR on customer satisfaction and loyalty in China: The moderating role of corporate image. Journal of Economics, Business and Management, 3(5), 542-547.

Cornelissen, J. P., Haslam, S. A. and Balmer, J. M. T. (2007). Social identity, organizational identity and corporate identity: Towards an integrated understanding of processes, patternings and products. British journal of management, 18, 1-16.

Erdoğan, i. (2012). Pozitivist metodoloji ve ötesi. Ankara: Erk Yayınları.

Flavián, C., Guinalíu, M. and Torres, E. (2005). The influence of corporate image on consumer trust: A comparative analysis in traditional versus internet banking. Internet Research, 15(4), 447-470.

Foroudi, P., Melewar, T. C. and Gupta, S. (2014). Linking corporate logo, corporate image, and reputation: An examination of consumer perceptions in the financial setting. Journal of Business Research, 67(11), 2269-2281.

Fortune Türkiye. (2018). Fortune 500 listesi. http://www.fortuneturkey.com/ fortune500. 10 October 2018.

Gatewood, R. D., Gowan, M. A. and Lautenschlager, G. J. (1993). Corporate image, recruitment image and initial job choice decisions. Academy of Management Journal, 36(2), 414-427.

82 | ETKíleşim |Yıl 4 |Sayı 7| Nisan 2021 
Gürbüz, S. and Şahin, F. (2016). Sosyal bilimlerde araştırma yöntemleri. Ankara: Seçkin Yayıncılık.

Hatch, M. J. and Schultz, M. (2008). Taking brand initiative: How companies can align strategy, culture, and identity through corporate branding. San Francisco: JosseyBass.

(2011). Marka girişimi: Kurumsal markalaşma ile şirket stratejisini, kültürünü ve kimliğini uyumlu hale getirme yöntemleri. İstanbul: Brandage.

Hu, H. H., Kandampully, J. and Juwaheer, T. D. (2009). Relationships and impacts of service quality, perceived value, customer satisfaction, and image: An empirical study. The Service Industries Journal, 29(2), 111-125.

Huang, C. C., Yen, S. W., Liu, C. Y. and Huang, P. C. (2014). The relationship among corporate social responsibility, service quality, corporate image and purchase intention. International Journal of Organizational Innovation (Online), 6(3), 68-84.

Ishaq, I. M. (2012). Perceived value, service quality, corporate image and customer loyalty: Empirical assessment from Pakistan. Serbian Journal of Management, $7(1), 25-36$.

Kara, M. and Kızılkaya, K. (2015). Köylere hizmet götürme birliklerinde hizmet kalitesinin ölçülmesi: Bayramiç köylere hizmet götürme birliği örneği. Organizasyon ve Yönetim Bilimleri Dergisi, 7(2), 1-18.

Karadoğan Doruk, S. and Savaş, S. (2017). Benzer sektörde faaliyet gösteren kurumların kuruluş tarihi sıralamasının kurum kültüründe ortaya çıkan yansımaları: Alfred Adler üzerinden Coca Cola ve Pepsi kurumları üzerine bir değerlendirme. İstanbul Üniversitesi iletişim Fakültesi Dergisi, 53, 103-137.

Kemp, S. (2018). Digital in 2018: World's internet users pass the 4 billion mark. https://wearesocial.com/blog/2018/01/global-digital-report-2018. 20.10.2018.

Kerr, J. and Slocum, J. W. (1987). Managing corporate culture through reward systems. Academy of Management Perspectives, 1(2), 99-107.

Kim, Y. E. and Lee, J. W (2010). Relationship between corporate image and customer loyalty in mobile communications service markets. African Journal of Business Management, 4(18), 4035-4041.

Ko, E., Hwang, Y. K., and Kim, E. Y. (2013). Green marketing functions in building corporate image in the retail setting. Journal of Business Research, 66(10), 17091715.

Liat, C. B., Mansori, S. and Huei, C. T. (2014). The associations between service quality, corporate image, customer satisfaction, and loyalty: Evidence from the Malaysian hotel industry. Journal of Hospitality Marketing \& Management, 23(3), 314-326.

Machen, A. W. (1911). Corporate personality. Harvard Law Review, 24(4), 253-267. 
Marangoz, M. (2006). Tüketicilerin marka fonksiyonu algılamaları ile satın alma sonrası davranışları arasındaki ilişki. Dokuz Eylül Üniversitesi iktisadi ve idari Bilimler Fakültesi Dergisi, 21(2), 107-128.

Marin, L. and Ruiz, S. (2007). 'I need you too'!. Corporate identity attractiveness for consumers and the role of social responsibility. Journal of Business Ethics, 71(3), 245-260.

Marken, G. A. (1990). Corporate image-we all have one, but few work to protect and project it. Public Relations Quarterly, 35(1), 21-23.

Mccrae, R. R. and Costa, P. T. (1982). Self-concept and the stability of personality: Cross-sectional comparisons of self-reports and ratings. Journal of Personality and Social Psychology, 43(6), 1282-1292.

Özgen, Ö. and Elmasoğlu, K. (2016). Sosyal medya ve marka iletişimi: Havayolu şirketlerinin Twitter kullanımına yönelik bir araştırma. iletişim Kuram ve Araştırma Dergisi, 43, 181-202.

Öztürk, G. and Tatlı E. (2014). Reklamcılıkta marka imajı yönetimi. G. Ilıcak Aydınalp (ed.), İmaj Üretimi (47-70). Ankara: Nobel Yayınları.

Page, R. (2014). Saying 'sorry': Corporate apologies posted on Twitter. Journal of Pragmatics, 62, 30-45.

Richard, J. E. and Zhang, A. (2012). Corporate image, loyalty, and commitment in the consumer travel industry. Journal of Marketing Management, 28(5-6), 568593.

Sadri, G. and Lees, B. (2001). Developing corporate culture as a competitive advantage. Journal of Management Development, 20(10), 853-859.

Sarantakos, S. (1993). Social research. London: Macmillian Press.

Savaş, S. (2016). Dunning-Kurger sendromu ve kurumsal dışavurum. Erciyes iletişim Dergisi, 4(3), 2-16.

Schein, E. H. (2009). The corporate culture survival guide. San Francisco: JosseyBass.

Tellis, G J., Prabhu, J. C. and Chandy, R. K. (2009). Radical innovation across nations: The preeminence of corporate culture. Journal of Marketing, 73(1), 3-23.

Tığlı, M. (2003). Kurum imajı kavramı ve sembolik analoji tekniği yoluyla Marmara Üniversitesi'nin kurum imajının belirlenmesine ilişkin bir uygulama. iktisadi ve idari Bilimler Dergisi, 18(1), 245-256.

Tsai, W. C. and Yang, I. W. F. (2010). Does image matter to different job applicants? The influences of corporate image and applicant individual differences on organizational attractiveness. International Journal of Selection and Assessment, 18(1), 2010, 48-63.

84 | ETKíleşim |Yıl 4 |Sayı 7 |Nisan 2021 
Van Den Bosch, A. L. M., De Jong, M. D. T. and Elving, W. J. L. (2005). How corporate visual identity supports reputation. Corporate Communications: An International Journal, 10(2), 108-116.

Virvilaite, R. and Daubaraite, U. (2011). Corporate social responsibility in forming a corporate image. Engineering Economics, 22(5), 534-543.

Vos, M. F. (1992). The corporate image concept: a strategic approach. Wageningen.

Weiwei, T. (2007). Impact of corporate image and corporate reputation on customer Loyalty: A Review. Management Science and Engineering, 1(2), 57-62.

Participant informed consent: Participants were informed before the data collection and they were asked to sign a form of consent.

Ethics committee approval: There is no need for ethics committee approval.

Conflict of interest: There are no conflicts of interest to declare.

Financial support: No funding was received for this study.

Author contribution rate: S. Savaş (50\%), S. Karadoğan Doruk (50\%).

Onam bilgisi: Katılımcılar işlem öncesinde bilgilendirilmiş, onam formu imzalatılmıştır.

Etik kurul onayı: Etik kurul onayına ihtiyaç bulunmamaktadır.

Çıkar çatış̧ası: Çıkar çatışması bulunmamaktadır.

Finansal destek: Finansal destek bulunmamaktadır.

Yazar katkı oranları: S. Savaş (\%50), S. Karadoğan Doruk (\%50). 